\title{
Biologinè terapija benralizumabu gydant sunkią eozinofilinę astmą. Privalumai ir kylantys klausimai
}

\author{
BIOLOGICAL THERAPY WITH BENRALIZUMAB IN SEVERE EOSINOPHILIC ASTHMA: \\ ADVANTAGES AND UNANSWERED QUESTIONS
}

\author{
VIRGINIJA KALINAUSKAITE்-ŽUKAUSKE் \\ LSMU MA Pulmonologijos klinika
}

\begin{abstract}
Santrauka. Biologinès terapijos sukūrimas yra proveržis eozinofilinės astmos gydyme. Slopinant interleukino-5 signalinį kelią, pvz., benralizumabu, veiksmingai mažinamas eozinofilinis uždegimas, retinami astmos paūmèjimai, pavyksta pasiekti geresnès astmos simptomų kontrolès, sumažinti geriamųjų gliukokortikoidų dozes arba juos visiškai nutraukti. Šis gydymas pasižymi ir geru saugumo profiliu. Tačiau kyla klausimų: ar sunaikinus eozinofilus ir pagerinus astmos kontrolę, nesumažinamas priešvirusinis eozinofilų poveikis? Ar neskatinama tumorogenezė? Atlikta nemažai tyrimų, kuriuose aktyviai diskutuojama šiais klausimais. Sergant eozinofiline astma, eozinofilai yra kitokie nei sveikų asmenų, todèl, juos sunaikinus, nepakanka pagrịstumo apie galimą žalą žmogaus sveikatai.

Reikšminiai žodžiai: sunki eozinofilinė astma, biologinė terapija, benralizumabas, eozinofilų sunaikinimas.

Summary. Biologic therapy is a breakthrough in the treatment of eosinophilic asthma. Inhibition of the interleukin-5 signalling pathway, such as with benralizumab, effectively reduces eosinophilic inflammation and asthma exacerbations, helps to achieve better control of asthma symptoms or a lower maintenance dose of glucocorticoids. Biologic therapy also has a good safety profile. However, there are the unaswered questions: does depletion of eosinophils not reduce the antiviral effects of eosinophils? Is tumorogenesis not promoted? A number of studies have been conducted to discuss these topics. In eosinophilic asthma, eosinophils are different from those in healthy individuals, so depletion is not a reasonable reason to think about the potential harm to human health.
\end{abstract}

Keywords: severe eosinophilic asthma, biological therapy, benralizumab, eosinophil depletion.

\section{IVADAS}

Astma yra paplitusi kvėpavimo takų liga, kuria serga daugiau nei 339 milijonai žmonių visame pasaulyje; maždaug 10 proc. jų serga sunkia arba nekontroliuojama astma $[1,2]$. Pastarąją tenka gydyti didelèmis inhaliuojamųjų gliukokortikoidų (IGK) ir ilgo veikimo $\beta_{2}$ agonistų (IVBA) dozėmis. Tačiau, nepaisant šiuo metu prieinamų gydymo būdų, sunki astma daugeliui pacientų vis dar išlieka problema. Biologinès terapijos sukūrimas prilyginamas perversmui gydant sunkią nekontroliuojamą eozinofilinę astmą dèl akivaizdaus gydymo veiksmingumo ir Pasaulinès astmos iniciatyvoje nurodomas kaip pridètinis eozinofilinès astmos gydymas, kai nepavyksta ligos kontroliuoti skiriant 4-5 gydymo pakopą [1]. Biologinès terapijos tikslas - eozinofilinio uždegimo slopinimas sergantiesiems sunkia eozinofiline astma [3-5]. Eozinofilų proliferacijai, brendimui, aktyvacijai, išlikimui svarbiausiu laikomas citokinas interleukinas (IL) 5 [6]. Todèl biologinès terapijos vaistai, skirti sunkiai eozinofilinei astmai gydyti, yra nukreipti į IL-5 signalini kelią: IL-5 antikūnai (anti-IL-5, pvz., mepolizumabas, reslizumabas) bei IL-5 receptorių a (IL-5Ra) antikūnai (benralizumabas). Eozinofilus naikinantis gydymas yra palyginti nauja astmai gydyti skirtų vaistų klasé, todèl svarbu suprasti eozinofilų sunaikinimo ilgalaiki veiksmingumą ir saugumą. Mokslininkai diskutuoja, ar nenukenčia imuninis atsakas, kokios galimos tokio gydymo rizikos, tikslinami šio gydymo privalumai ir trūkumai. Ypatingas dėmesys skiriamas piktybinių navikų ir sunkių infekcijų rizikai.

\section{BENRALIZUMABO VEIKSMINGUMAS GYDANT SUNKIĄ EOZINOFILINĘ ASTMĄ}

Benralizumabas yra biologinès terapijos sunkiai eozinofilinei astmai gydyti atstovas- tai IL-5Ra monokloninis antikūnas, kuris veikia citolitiškai: veiksmingai ardo kraujo ir audinių eozinofilus per nuo antikūnų priklausomą ląstelių citotoksiškumą (natūralios žudikès ląstelès sukelia ląstelių apoptozę) ir įvyksta tiesioginis, greitas ir beveik visiškas eozinofilų sunaikinimas [7]. Benralizumabas skirtas pacientams, sergantiems sunkia, nekontroliuojama astma, esant išreikštam eozinofiliniam uždegimui. Gydymo 
A Eozinofilų kiekis kraujyje $\geq 300$ ląstelių/ $\mu \mathrm{l}$

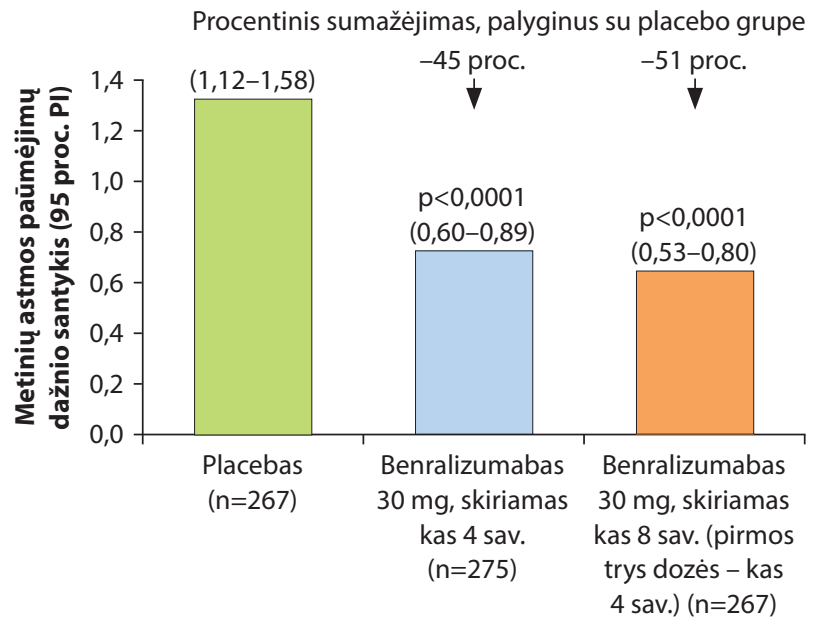

Eozinofilų kiekis kraujyje $<300$ ląstelių/ $\mu \mathrm{l}$

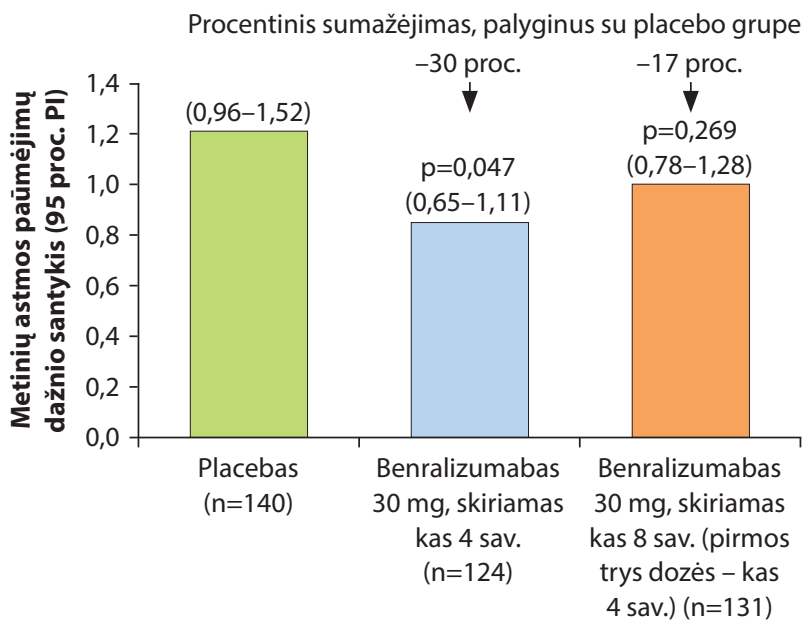

1 pav. Remiantis pradiniu eozinofilų kiekiu kraujyje, îvertintas astmos paūmèjimo dažnis $\mathbf{4 8}$ gydymo savaitę: (A) pateikti duomenys pacientų, kurių pradinis kraujo eozinofilų kiekis buvo $\geq 300$ ląstelių viename $\mu$ l; (B) pateikti duomenys pacientų, kurių pradinis kraujo eozinofilų kiekis buvo <300 ląstelių viename $\mu l$

Iverčiai buvo apskaičiuoti naudojant neigiamą binomini modeli, pritaikant pagal skiriamą gydymą, regioną, geriamujų GKS vartojimą ir ankstesnius paūmèjimus [8].

Santrumpa: PI - pasikliautinasis intervalas.

veiksmingumas patvirtintas didelès imties tyrimuose, kurių vieni didžiausių - SIROCCO [8], CALIMA [9], ZONDA [10] tyrimai.

SIROCCO atsitiktinių imčių dvigubai aklame, paralelinių grupių, placebu kontroliuotame trečios fazès klinikiniame tyrime dalyvavo 1205 asmenys, atsitiktine tvarka suskirstyti $\mathfrak{i}$ tris grupes: placebo, $30 \mathrm{mg}$ benralizumabo, skiriamo kas keturias savaites, grupę, ir 30 mg benralizumabo, skiriamo kas aštuonias savaites. Didžiosios dalies tiriamųjų eozinofilų kiekis kraujyje buvo $\geq 300$ ląstelių/ $\mu$ l. Palyginus su placebu, per 48 pridètinio gydymo benralizumabu savaites metinis astmos paūmėjimų dažnis reikšmingai sumažėjo: skiriant benralizumabą kas keturias savaites, dažnio santykis (DS) buvo $0,55,95$ proc. pasikliautinasis intervalas (PI) $0,42-0,71 ; \mathrm{p}<0,0001$; skiriant kas aštuonias savaites - DS 0,49, 95 proc. PI 0,37-0,64; $\mathrm{p}<0,0001$ (1 pav.). Nustatytas ryškus $\mathrm{FEV}_{1}$, išmatuoto 48 tyrimo savaitę prieš skiriant bronchus plečiančių vaistų, padidejimas nepriklausomai nuo benralizumabo dozavimo schemos, palyginus su placebu (mažiausių kvadratų vidutinis pokytis, palyginus su pradiniu: skiriant benralizumabą kas keturias savaites - 0,106 1, 95 proc. PI 0,016-0,196; skiriant benralizumabą kas aštuonias savaites - 0,159 1, 95 proc. PI 0,068-0,249) (2 pav.). Akivaizdus astmos simptomų pagerejjimas, palyginus su placebu, nustatytas skiriant benralizumabą kas aštuonias savaites (pirmos trys dozès kas keturias savaites; mažiausių kvadratų skirtumai -0,25, 95 proc. PI $-0,45 \mathrm{iki}-0,06)$, bet ne kas keturias savaites $-(-0,08$, $-0,27-0,12)$.

Panaši benralizumabo efektyvumo tendencija stebèta ir analogiško dizaino tyrime CALIMA, i kurị itraukti 1306 asmenys, sergantys sunkia eozinofiline astma (3, 4 pav.).

Taip pat nustatyta, kad benralizumabas vos per 2 dienas nuo gydymo pradžios pagerina rytinị didžiausią iškvèpimo srovès greiti (angl. peak expiratory flow, PEF) [8-10]. Kliniškai reikšmingas PEF pokytis nustatytas septintą gydymo dieną (vidutinis PEF padidejimas, lyginant su pradine verte, buvo 21,69 1/min., gydant benralizumabu, ir 5,15 l/min., vartojusiems placebą). Toks PEF pokytis rodo, kad unikalus benralizumabo veikimo mechanizmas greitai pagerina pacientų, sergančių sunkia eozinofiline astma, plaučių funkciją [11].

Jungtinès SIROCCO ir CALIMA tyrimų analizès duomenimis, benralizumabo fone trečią dieną po pirmos injekcijos nustatytas statistiškai patikimai reikšmingas trumpo veikimo $\beta_{2}$ agonistų (TVBA) poreikio sumažejimas. TVBA poreikis sumažejo 0,71 ikvépimo (95 proc. PI -1,12 - (-0,29), $\mathrm{p} \leq 0.001)$, vartojant benralizumabą kas aštuonias savaites, palyginus su placebu. Apskritai pacientų, vartojusių benralizumabą kas aštuonias savaites, kasdien suvartojamų TVBA poreikis vidutiniškai sumažejo nuo 4,4 ikvejpimų iki 1,47 ikvépimo (tyrimo pabaigoje) (5 pav.) [12].

Daugelis pacientų, sergančių sunkia astma, norèdami kontroliuoti astmos simptomus, vartoja geriamuosius gliukokortikoidus (GGK). Atliktas tyrimas ZONDA, kurio metu vertinta, ar benralizumabas taip pat veiksmingas ir GGK vartojantiems pacientams, sergantiems sunkia astma su išreikšta eozinofilija [10]. 220 tiriamųjų atsitiktinès atrankos būdu buvo suskirstyti ị benralizumabo (skiriamo tiek kas keturias, tiek kas aštuonias savaites režimu) ir placebo grupes. Abi benralizumabo dozavimo schemos reikšmingai sumažino vidutinę 


\section{Farmakoterapija}

GKK dozę 75 proc., palyginus su pradine vaistų doze, o placebo grupeje - tik 25 proc. $(\mathrm{p}<0,001$ abiem atvejais) (5 pav., A). Vartojant benralizumabą, GKK dozès sumažejiimo tikimybè buvo daugiau kaip keturis kartus didesnè nei vartojant placebą. Taip pat nustatyta, kad, skiriant benralizumabą kas keturias savaites, metinis paūmejjimo dažnis buvo 55 proc. mažesnis nei placebo grupeje $(0,83$, palyginus su $1,83, \mathrm{p}=0,003)$, o benralizumabą vartojant kas aštuonias savaites (pirmos trys dozès kas keturias savaites) - 70 proc. mažesnis nei vartojant placebą $(0,54$, palyginus su $1,83, \mathrm{p}<0,001)$ (6 pav., B). 28 savaitę, vertinant abu benralizumabo vartojimo režimus, nenustatyta reikšmingo poveikio $\mathrm{FEV}_{1}$, palyginus su placebu. Taigi, benralizumabas, palyginus su placebu, parodè kliniškai reikšmingą pranašumą, mažinant GGK dozę ir astmos paūmẻjimų dažní, palyginus su placebu. Šis poveikis pasireiškè nedarant ilgalaikio poveikio $\mathrm{FEV}_{1}$.

Šie rezultatai patvirtina benralizumabo veiksmingumą ir saugumą pacientams, sergantiems sunkia astma ir turintiems padidejusị kraujo eozinofilų kiekị, kai astma nekontroliuojama skiriant dideles IGK ir IVBA dozes.

\section{EOZINOFILŲ APSAUGINĖS FUNKCIJOS SVARBA}

Eozinofilai yra pagrindiniai „kaltininkai“ sergant eozinofiline astma, reikšmingai prisideda prie astmos patogenezès ir kvèpavimo takų remodeliacijos, tačiau jie yra ir imuninès ląstelès, kurios svarbios apsaugant nuo virusinių, bakterinių patogenų, kovojant su helmintine infekcija $[13,14]$.

Kai kurie eozinofilų granulèse esantys baltymai turi priešvirusini poveiki [15]. Kitas galimas priešvirusinis mechanizmas yra eozinofilų gaminamas azoto oksidas [16]. Be to, virusų arba virusuc peptidais veikiami eozinofilai gali sukelti CD8+T ląstelių dauginimąsi ir aktyvaciją, taip skatindami ląstelinị imunitetą prieš virusus [17]. Priešvirusinis eozinofilų aktyvumas pelių modelyje nustatytas esant ịvairioms virusinėms kvėpavimo takų infekcijoms, ìskaitant gripą, paragripą, žmogaus imunodeficito virusą (ŽIV) [17, 18-20].

Yra duomenų, kad eozinofilus gali suaktyvinti ir tam tikros bakterijos, kurias jie sunaikina, o eozinofilopenija yra būdingas modeliuotų ūminių bakterinių
A Eozinofilų kiekis kraujyje $\geq 300$ ląstelių/ $\mu \mathrm{l}$

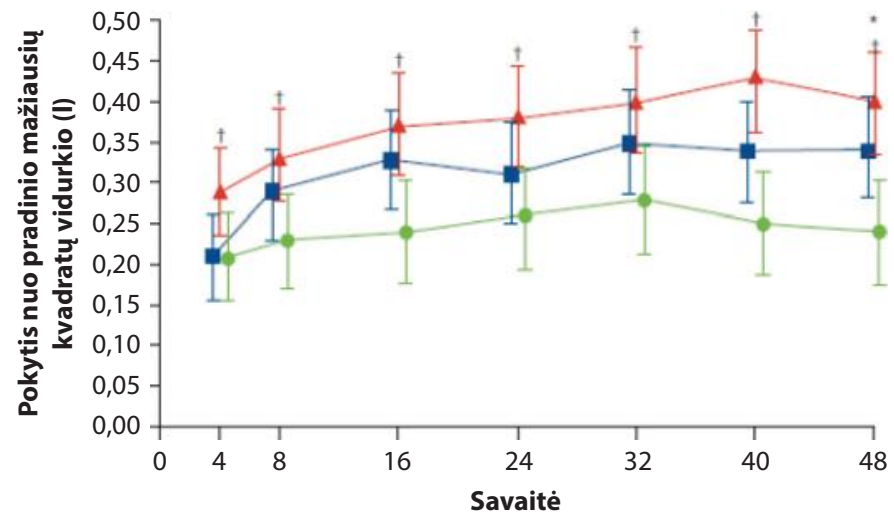

Tiriamujų kiekis (n)

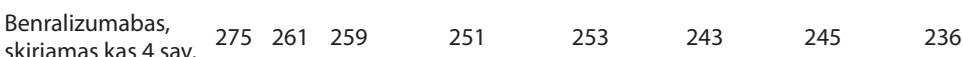

Benralizumabas,

$\begin{array}{lllllllll}\text { skiriamas kas 8 sav. } & 267 & 251 & 258 & 250 & 251 & 240 & 236 & 235\end{array}$

dozès - kas 4 sav.)

$\begin{array}{lllllllll}\text { Placebas } & 267 & 249 & 253 & 246 & 247 & 238 & 232 & 233\end{array}$

B Eozinofilų kiekis kraujyje $<300$ ląstelių/ $\mu$ l

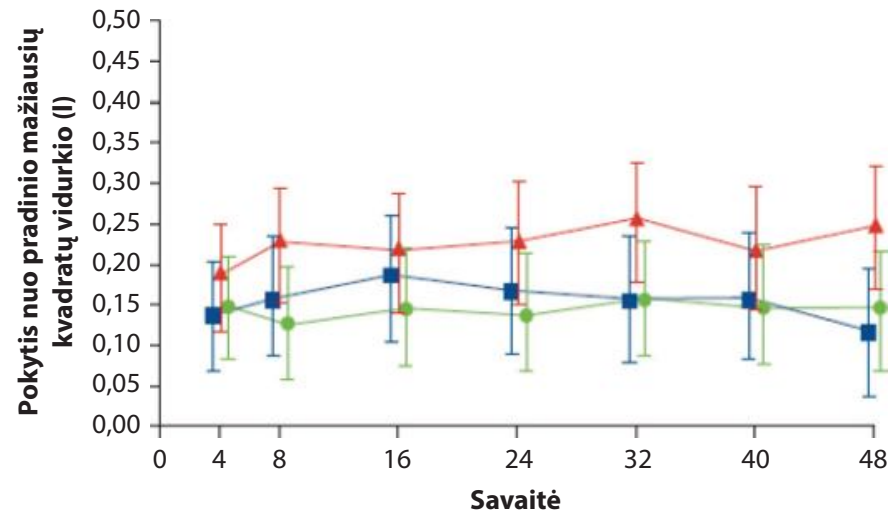

Tiriamujų kiekis (n) $\begin{array}{lllllllll}\text { skiriamas kas } 4 \text { sav. } & 124 & 117 & 116 & 114 & 111 & 107 & 107 & 105\end{array}$ Benralizumabas, $\begin{array}{lllllllll}\begin{array}{l}\text { skiriamas kas 8 sav. } \\ \text { (pirmos trys }\end{array} & 131 & 125 & 123 & 123 & 121 & 117 & 116 & 119\end{array}$ dozès - kas 4 sav.)

$\begin{array}{lllllllll}\text { Placebas } & 140 & 133 & 135 & 125 & 128 & 128 & 122 & 125\end{array}$

- Placebas
- Benralizumabas, skiriamas kas 4 sav.
- Benralizumabas, skiriamas kas 8 sav. (pirmos trys dozès - kas 4 sav.)

2 pav. Forsuoto iškvèpimo tūrio per pirmają sekundę $\left(\mathrm{FEV}_{1}\right)$, išmatuoto prieš skiriant bronchus plečiančių vaistų, pokytis, atsižvelgiant ị pradinị kraujo eozinofilų kiekį kraujyje: (A) pateikti duomenys pacientụ, kurių pradinis kraujo eozinofilų kiekis buvo $\geq 300$ ląstelių/ $\mu$ l; (B) pateikti duomenys pacientu, kurių pradinis kraujo eozinofilų kiekis buvo $<300$ ląstelių/ul [8]

* $p<0,05$, kai vartojamas 30 mg benralizumabo kas keturias savaites, palyginus su placebu: $+p<0,05$, kai vartojamas $30 \mathrm{mg}$ benralizumabo kas aštuonias savaites, palyginus su placebu. infekcijų požymis $[21,22]$. Pastebėtas atvirkštinis ryšys tarp bakterijų kiekio ir periferinio kraujo eozinofiluc [23], o eozinofilopenija gali sudaryti sąlygas bakterinès kilmès sepsiui vystytis [24]. 
A Eozinofilų kiekis kraujyje $\geq 300$ ląstelių/ $\mu \mathrm{l}$

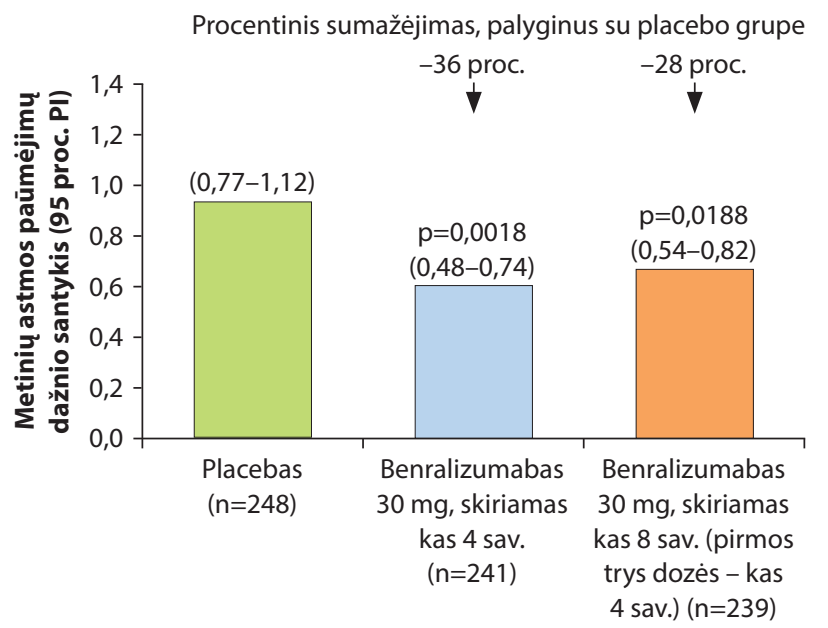

Eozinofilų kiekis kraujyje $<300$ ląstelių/ $\mu \mathrm{l}$

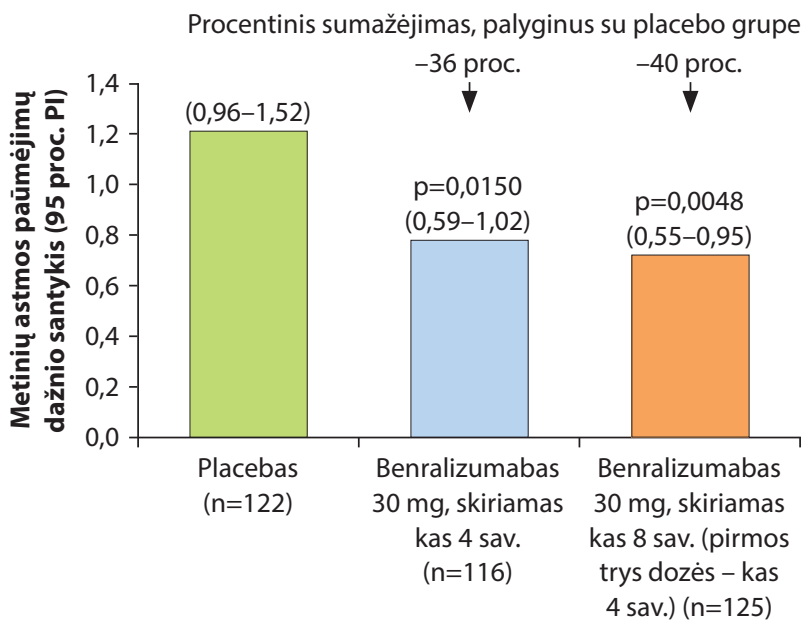

3 pav. Metinis astmos paūmèjimo dažnio sumažèjimas po 56 savaičių pacientams, vartojusiems dideles IGK ir IVBA dozes, kai pradinis kraujo eozinofilų kiekis yra: (A) $\geq 300$ ląstelių/ $\mu \mathrm{l} ;(B)<300$ ląstelių/ $\mu$ l (pilna analizè) [9]

Eozinofilija yra dažnas šeimininko atsakas ir ị helmintinę infekciją. Tradiciškai eozinofilai in vitro yra imuninès ląstelès, kurios apsaugo nuo ịvairių kirminų lervų formų. Tačiau naujausi tyrimai, panaudojant gyvūnų modelius, parodè, kad eozinofilai gali turèti neigiamą poveikį šeimininkui priklausomai nuo parazito rūšies, infekcijos vietos ir nuo to, ar infekcija yra pirminè, ar antrinè [25]. Tačiau pastebèta, kad eozinofilai palaiko kai kurių parazitų augimą ir juos tarsi apsaugo [26, 27], ypač esant pirminėms ne žarnyno kilmès infekcijoms, užkerta kelią toksiniam imuniniam atsakui ir lervų sunaikinimui [25]. Šie duomenys rodo eozinofilų poveikị tiek apsaugant nuo helmintų, tiek sudarant sąlygas jų vystymuisi.

Atsižvelgiant ị tai, kad priešinfekcinis eozinofilų atsakas būna ne visomis aplinkybėmis, svarstoma, ar toks jų priešinfekcinis veikimas nèra labiau priklausomas nuo aktyvacijos proceso nei nuo aktyvuotų eozinofilų skaičiaus [28].

Astma yra lètinè uždegiminè kvèpavimo takų liga, kuriai būdingi periodiniai paūmèjimai, paprastai pabloginantys sergančiojo plaučių funkciją, gyvenimo kokybę, padidinantys gydymui tenkančias išlaidas, o sergant sunkia astma gali baigtis ir mirtimi. Viena dažniausių astmos paūmèjimo priežasčių - virusinè infekcija. Esant eozinofilinès astmos paūmèjimui, patogenetiškai randamas ir suintensyvejjęs lètinis eozinofilinis uždegimas. Taigi, kyla klausimas, ar biologinès terapijos (tiek anti-IL-5, tiek anti-IL-5Ra) skyrimas (tęstinis, ne naujai pradètas) nenuslopina priešvirusinio eozinofilų aktyvumo? Ankstesni tyrimai parodè, kad dèl anti-IL-5 sukelto eozinofilų sunaikinimo padaugejjo A gripo viruso kopijų namų dulkių erkėmis ijautrintų pelių modelyje [29] arba rinoviruso-16 kopijų žmonèms, sergantiems astma [30].

Viename atliktų tyrimų IL-5 transgeninių pelių eozinofilija buvo siejama su greitesniu pasveikimu po užkrètimo nemirtina A gripo viruso doze [20]. Didžioji dalis kvẻpavimo takų eozinofilų prisijungè A gripo virusą ir tapo aktyvuoti. Panašiai sveikų žmonių eozinofilai sugebejjo veiksmingai surišti ir inaktyvuoti respiracinị sincitinị virusą bei A gripo viruso daleles ir taip aktyvuotis. Priešingai, sunkia astma sergančių pacientų eozinofilai pasižymi mažesniu viruso surišimo gebejjimu [30]. Remiantis šiais duomenimis, galima teigti, kad suaktyvinti eozinofilai turi mažesnị priešvirusinị poveikị [30].

Apžvelgus turimus duomenis, manoma, kad priešvirusinis eozinofilų aktyvumas sergantiesiems astma ir sveikiems asmenims skiriasi [28] (7 pav.). Sveikiems asmenims virusinė infekcija suaktyvina eozinofilus, todèl padideja ịvairūs paviršiaus aktyvacijos žymenys (pvz., CD69) ir išsiskiria eozinofiliniai katijoniniai baltymai bei kiti eozinofilų granulių baltymai. Be to, aktyvuoti eozinofilai greitai prisijungia ir inaktyvuoja viruso daleles, taip prisideda prie virusų kiekio kontrolès ir greito pasveikimo. Ši eozinofilų savybè turbūt yra svarbus antivirusinis imuninès gynybos mechanizmas. Astma sergančiųjų eozinofilai yra pradinès būsenos ir nuolat aktyvuojami. Po virusinių infekcijų jie pasižymi padidejusiomis citotoksinemis savybèmis. Dèl ankstesnio aktyvavimo astmos eozinofilai turi mažiau galimybių surišti ir inaktyvinti virusą - visa tai tikriausiai leidžia vystytis didesniam viruso kiekiui ir prisideda prie virusų sukeltų astmos paūmèjimų. Šis priešvirusinis eozinofilų nepakankamumas sergantiesiems astma gali būti kitoks vartojant ịkvepiamuosius gliukokortikoidus ir prieš IL-5 kelią nukreiptą gydymą. Manoma, kad tam itakos gali turèti skirtingų eozinofilų fenotipų indèlis $\mathfrak{i}$ antivirusinị atsaką, kuris dar nepakankamai ištirtas.

Taigi, ịvertinus tai, kad, sergant astma, eozinofilų funkcija yra pakitusi ir tai gali prisideti prie dažnes- 


\section{Farmakoterapija}

nių viruso sukeltų paūmèjimų, tikètina, kad tokių eozinofilų sunaikinimas gali mažinti ligos paūmèjimų riziką. Svarbu dar ir tai, kad dèl specifinio vaisto veikimo mechanizmo neišskiriami eozinofilų degranuliacijos produktai, turintys žalojamąji poveiki, todèl neskatinamas eozinofilinis uždegimas.

\section{SKIRTINGI EOZINOFILŲ FENOTIPAI}

Eozinofilai diferencijuojasi iš pluripotentinių ląstelių veikiami citokinų ir augimo veiksnių. IL-5 laikomas esminiu eozinofilų diferenciacijai ir brendimui kaulų čiulpuose, dar vadinamas eozinofilopoetinu [31]. Subrendę eozinofilai patenka ị kraujotaką, o veikiami citokinų, eotaksinų ir kitų biologiškai aktyvių medžiagų, migruoja i audinius. Paprastai šie eozinofilai vadinami uždegiminiais eozinofilais.

Neseniai identifikuoti specifiniai homeostatiniai plaučių parenchimos, dar vadinami rezidentiniai eozinofilai [32]. Šie eozinofilai sudaro unikalią ir savitą eozinofilų populiaciją, kuri priešingai nei klasikiniai uždegiminiai eozinofilai atlieka pagrindines reguliavimo ir imuninę sistemą slopinančias funkcijas ir tarsi „gyvena“ plaučiuose $[33,34]$. Plaučių rezidentiniai eozinofilai skiriasi nuo uždegiminių eozinofilų skaičiumi, vieta, morfologinèmis, fenotipinėmis bei transkriptominèmis savybèmis ir išlieka nepakitę tiek provokuojant alergenu, tiek kvèpavimo takų uždegimo metu [35]. Tai rodo, kad astmos patogenezei ir ligos eigai gali būti svarbi sutrikusi pusiausvyra tarp uždegiminių ir rezidentinių eozinofilų, o ne paprasčiausias uždegiminių eozinofilų pagausejjimas [28].

Aukščiau straipsnyje aprašyti tyrimai orientuoti ị uždegiminius eozinofilus. Tačiau vaisto efektyvumas neatsiejamas nuo eozinofilų sunaikinimo ne tik kraujyje, bet ir lokaliai - kvèpavimo takuose.

Pacientams, sergantiems sunkia eozinofiline astma, skrepliuose randama dešimt kartų daugiau eozinofilų linijos progenitorinių ląstelių (CD34+CD45+IL$5 \mathrm{R} a+$ ) nei pacientams, sergantiems lengva astma, nepaisant panašaus šių ląstelių skaičiaus kraujyje [36]. Palyginus su lengva astma sergančių pacientų eozinofilų linijos progenitorinėmis ląstelèmis, pacientams, sergantiems sunkia astma, nustatytas didesnis eozinofilų / bazofilų kolonijas sudarančių vienetų in vitro augimas, kurị slopina
A Eozinofilų kiekis kraujyje $\geq 300$ ląstelių/ $\mu \mathrm{l}$

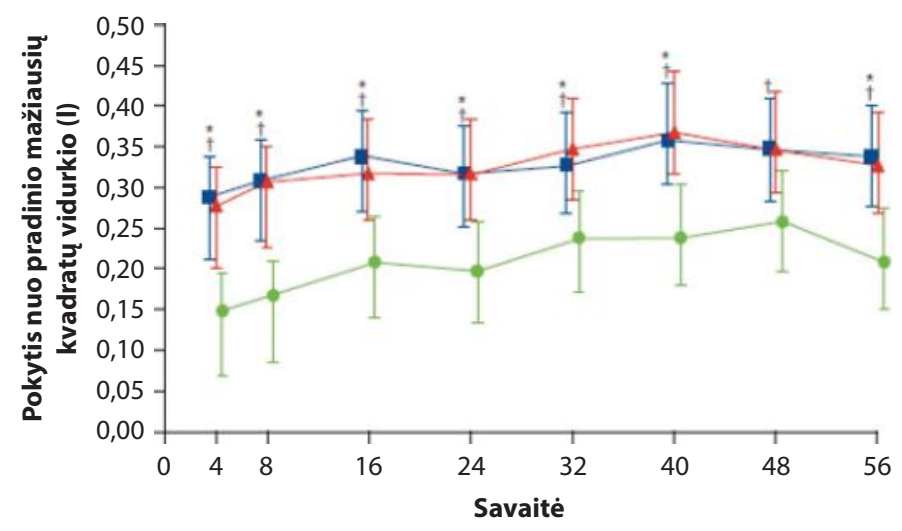

Tiriamujų kiekis (n)

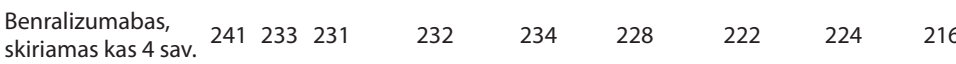

Benralizumabas,

$\begin{array}{llllllllll}\text { skiriamas kas 8 sav. } & 239 & 232 & 230 & 223 & 222 & 225 & 218 & 217 & 211\end{array}$

dozès - kas 4 sav.)

$\begin{array}{llllllllll}\text { Placebas } & 248 & 236 & 240 & 240 & 235 & 231 & 224 & 224 & 221\end{array}$

B Eozinofilų kiekis kraujyje $<300$ ląstelių/ $\mu \mathrm{l}$

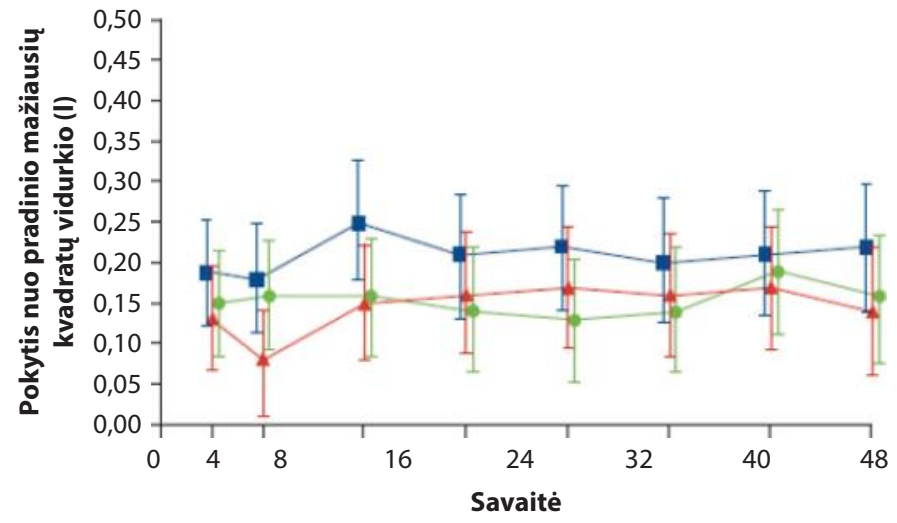

Tiriamujų kiekis (n)

Benralizumabas, $116 \quad 112 \quad 111 \quad 108 \quad 106 \quad 106 \quad 105 \quad 101$

skiriamas kas 4 sav. $116112 \quad 111 \quad 108 \quad 106 \quad 106 \quad 105 \quad 101 \quad 10$

Benralizumabas,

$\begin{array}{llllllllll}\text { skiriamas kas 8 sav. } & 125 & 120 & 115 & 116 & 110 & 105 & 105 & 102 & 98\end{array}$

dozès - kas 4 sav.)

$\begin{array}{llllllllll}\text { Placebas } & 122 & 107 & 112 & 110 & 100 & 105 & 102 & 102 & 99\end{array}$

- Placebas
- Benralizumabas, skiriamas kas 4 sav.
- Benralizumabas, skiriamas kas 8 sav. (pirmos trys dozès - kas 4 sav.)

4 pav. Forsuoto iškvėpimo tūrio per pirmają sekundę $\left(F E V_{1}\right)$, išmatuoto prieš skiriant bronchus plečiančių vaistų, pokytis, atsižvelgiant į pradinị kraujo eozinofilų kiekį kraujyje: (A) pateikti duomenys pacientų, kurių pradinis kraujo eozinofilų kiekis buvo $\geq 300$ ląstelių/ $\mu$ l; (B) pateikti duomenys pacientu, kurių pradinis kraujo eozinofilų kiekis buvo $<300$ ląstelių/ $\mu$ l [9] * $p<0,05$, kai vartojamas $30 \mathrm{mg}$ benralizumabo kas keturias savaites, palyginus su placebu;
$+p<0,05$, kai vartojamas 30 mg benralizumabo kas aštuonias savaites, palyginus su placebu. IL-5R blokuojantys antikūnai [36]. Todèl manoma, kad nuolatinè kvėpavimo takų eozinofilija, sergant sunkia astma, yra lokalios nuo IL-5 sąlygotos eozinofilopoezès priežastis. 


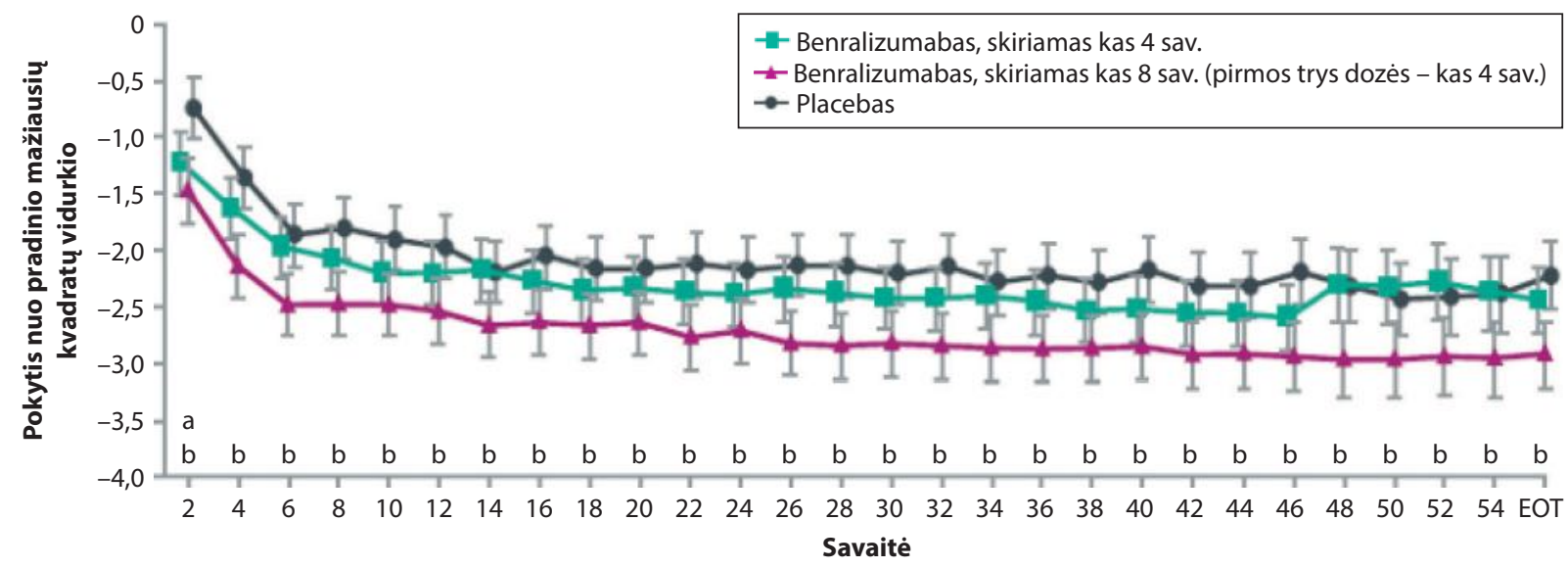

Tiriamujų kiekis (n)

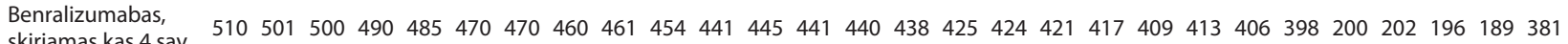

skiriamas kas 4 sav.

skiriamas kas 8 sav.

(pirmos trys dozes - $494482478474467457452437435426427415412409411403392 \quad 396 \quad 398387384370379194193 \quad 191 \quad 192 \quad 363$ kas 4 sav.)

Placebas $\quad 509501491486482469457449455435443435435429422418414411408402396402392196197190186367$

5 pav. Trumpo veikimo $\beta_{2}$ agonistų vartojimo sumažèjimas, skiriant benralizumabą ir dideles IGK / IVBA dozes (jungtinè analizè; kraujo eozinofilų skaičius $\geq 300$ ląstelių/ $\mu$ l) [12]

Santrumpos: IGK - ikvepiamieji gliukokortikoidai; IVBA - ilgo veikimo $\beta_{2}$ agonistai.

Atliktas tyrimas [10], kurio metu vertina, ar blokuojant IL-5 / IL-5R aši, gali sumažèti nuolatinè kvépavimo takų eozinofilija. I tyrimą iš keturių akademinių centrų i̇traukta 18 pacientų, sergančių sunkia astma, turinčių padidejusị eozinofilų kiekị kraujyje ir astmos simptomų kontrolei palaikyti vartojančių GGK. Po steroidų optimizavimo etapo 28 savaites pacientai vartojo $30 \mathrm{mg}$ benralizumabo i̇ poodị kas keturias savaites $(n=4)$ arba kas aštuonias savaites (pirmosios trys dozès kas keturias savaites; $\mathrm{n}=7$ ), arba placebą kas keturias savaites $(\mathrm{n}=7)$. Abiejų vaistų vartojimo režimų rezultatai buvo apibendrinti $(n=10$; vienas pacientas benralizumabo grupejje anksti pasitraukè dèl nepageidaujamų poveikių, o šio paciento duomenys nebuvo ịtraukti ị galutinę analizę) ir buvo lyginami su placebu $(\mathrm{n}=7)$.

Benralizumabas, palyginus su placebu, reikšmingai sumažino subrendusių eozinofilų kiekị kraujyje ir skrepliuose. Eozinofilų linijos progenitorinių ląstelių, aptiktų srauto citometrijos būdu kraujyje po gydymo benralizumabu, palyginus su placebu, taip pat reikšmingai sumažejo. Panašus poveikis, vartojant benralizumabą, nustatytas ir skrepliuose, nors reikšmingai nesiskyre nuo placebo greičiausiai dẻl mažo suderintų duomenų rinkinių skaičiaus (benralizumabo grupèje $n=7$, placebo grupejje $\mathrm{n}=5$ ). Atlikus 14 dienų klonogeninès kultūros tyrimus, benralizumabo grupéje žymiai sumažèjo IL-5 skatinamas eozinofilų / bazofilų kolonijas sudarančių vienetų augimas, palyginus su placebo grupe.

Skrepliuose stebèta panaši tendencija, nors šie pokyčiai nebuvo reikšmingi greičiausiai dèl mažo mèginių dydžio. Nustatytas IL-5 padidejimas galejo atsirasti dèl
IL-5Ra+ ląstelių sunaikinimo, o ne dèl kompensacinių homeostatinių procesų, nes reikšmingo 2-o tipo uždegimo kraujo ir skreplių ląstelių, ekspresuojančių IL-5, kiekio padidejimo nenustatyta. Reikšmingas granzimo B ir interferono $\gamma$ kiekio padidejjimas skrepliu supernatantuose be ląstelių rodo padidejusị natūralių žudikių ląstelių aktyvumą vartojant benralizumabą, palyginus su placebu.

Taigi, duomenys rodo, kad benralizumabas žymiai sumažino subrendusių eozinofilų ir eozinofilų linijos progenitorinių ląstelių kiekị tiek kraujyje, tiek skrepliuose (8 pav.). Šie pokyčiai buvo susiję su palaikomosios GGK dozès sumažinimu, astmos kontrolès pagerèjimu ir padidejjusia plaučiu funkcija po gydymo benralizumabu.

\section{IMUNINIO ATSAKO FORMAVIMASIS BENRALIZUMABO FONE}

Astma susijusi su padidejjusiu jautrumu infekcijoms [39]. Paprastai tai būna antrinès kilmès infekcijos, ypač pacientams, sergantiems sunkia astma. Yra ịrodymų, kad ir IGK taip pat gali būti susiję su padidejusia kvèpavimo takų infekcijos rizika [40].

Gripas neretai siejamas su astmos išsivystymu, ligos paūmẻjimais tiek suaugusiesiems, tiek vaikams, sergantiems astma [41]. Astmos sukeliamas lètinis kvèpavimo takų uždegimas ir 2 tipo imuninis atsakas sumažina sergančių astma pacientų kvejpavimo takų priešvirusinị imunitetą [42]. Taigi, palyginus su bendrąja populiacija, astma sergantiems pacientams taip pat padidejja su gripu susijusių komplikacijų rizika [42]. Nors turimų 


\section{Farmakoterapija}

A Geriamojo gliukokortikoido dozès pokytis palyginus su pradine

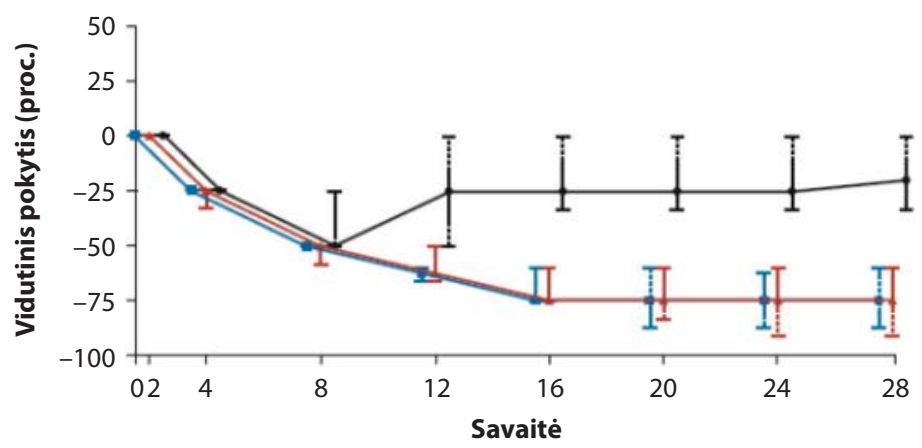

Tiriamujų skaičius (n)

$\begin{array}{lllllllll}\begin{array}{l}\text { Benralizumabas, } \\ \text { skiriamas kas 4 sav. }\end{array} & 72 & 70 & 70 & 69 & 69 & 68 & 66 & 68\end{array}$

Benralizumabas,

$\begin{array}{lllllllll}\text { skiriamas kas 8 sav. } & 70 & 72 & 67 & 69 & 69 & 66 & 69 & 68\end{array}$

(pirmos trys

dozès - kas 4 sav.)

Placebas

$74 \quad 75$

$\multimap$ Placebas

- Benralizumabas, skiriamas kas 4 sav.

$\rightarrow$ Benralizumabas, skiriamas kas 8 sav. (pirmos trys dozès - kas 4 sav.)

B Laikas iki pirmo astmos paūmèjimo

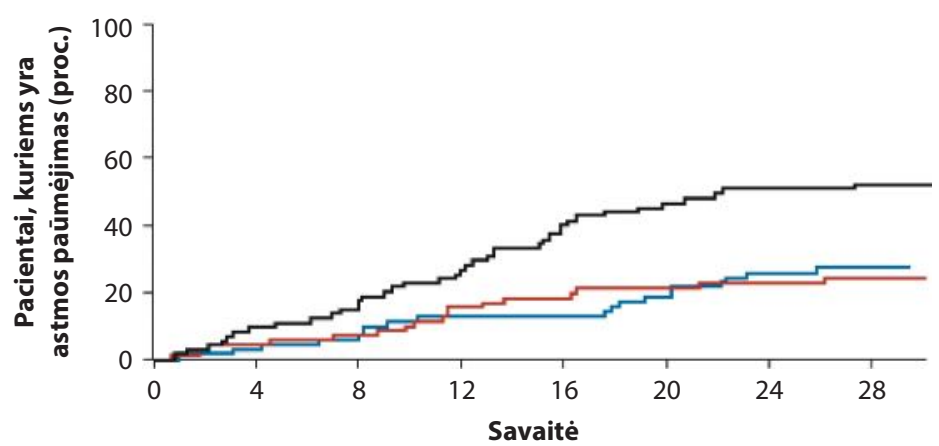

Tiriamujų skaičius (n)

Benralizumabas, skiriamas kas 4 sav. 72

Benralizumabas,

$\begin{array}{lllllllll}\text { skiriamas kas } 8 \text { sav. } & 73 & 68 & 66 & 60 & 58 & 56 & 55 & 51\end{array}$

dozès - kas 4 sav.)

Placebas 75

$\begin{array}{llllllll}75 & 68 & 64 & 56 & 45 & 40 & 37 & 31\end{array}$

- Placebas
- Benralizumabas, skiriamas kas 4 sav.
- Benralizumabas, skiriamas kas 8 sav. (pirmos trys dozès - kas 4 sav.)

6 pav. Geriamujų gliukokortikosteroidų dozès $(A)$ ir astmos paūmèjimų dažnio (B) pokytis per 28 tyrimo savaites [10]

duomenų daugiausia yra iš stebėsenos tyrimų, skiepai nuo gripo buvo susieti su retesniais astmos paūmejjimais ir gripo komplikacijomis, mažesnemis sveikatos priežiūros išlaidomis [42]. Kadangi benralizumabas yra imunomoduliatorius, svarbu nustatyti, ar jis daro ịtaką imuninès sistemos funkcionavimui, ịskaitant atsaką í skiepus nuo gripo šioje rizikos grupeje. Todèl buvo ištirta, ar benralizumabas keičia reakciją i gripo skiepus. Beje, skiepai skatina organizmą gaminti antikūnus. Siekiant ịvertinti galimus imuninio atsako

Eozinofilai

(uždegiminiai/rezidentiniai)

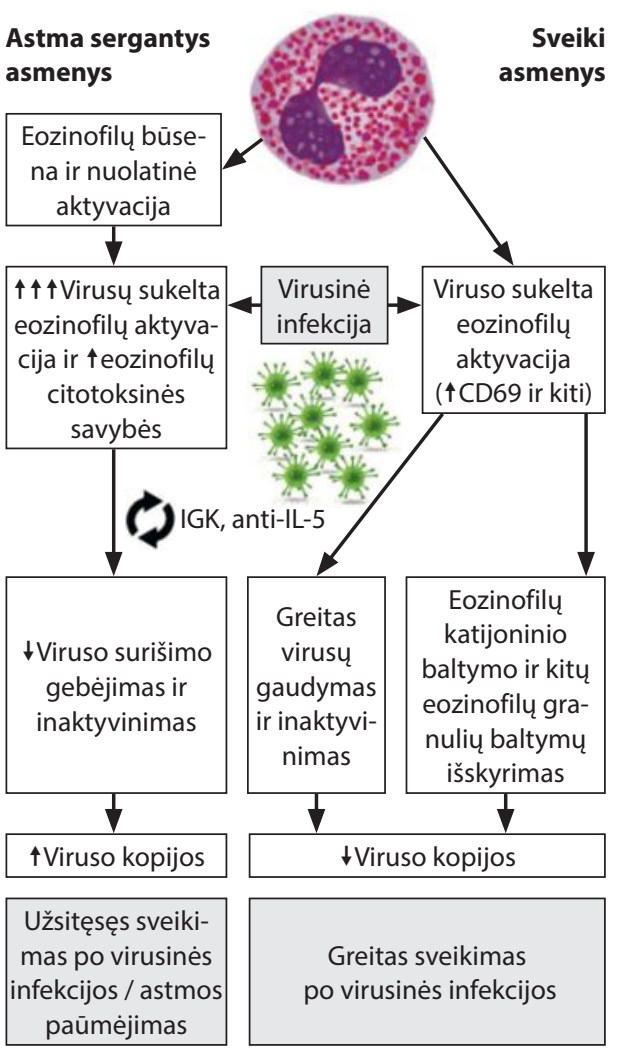

7 pav. Priešvirusinis eozinofilų aktyvumas sergantiesiems astma ir sveikiems asmenims [28]

Santrumpos: IGK - įkvepiamieji gliukokortikoidai.

pokyčius, gydant benralizumabu, atliktas IIIb fazès atsitiktinių imčių kontroliuojamasis tyrimas ALIZE [43], kurio metu vertinta, ar trys benralizumabo dozès keičia antikūnų atsaką ì sezoninio gripo skiepus paaugliams / jauniems suaugusiems pacientams, sergantiems vidutinio sunkumo arba sunkia astma. Tyrime dalyvavo 103 (12-21 metų) pacientai, vartoję vidutines arba dideles IGK / IVBA dozes. Benralizumabas arba placebas skirtas iš pradžių ketvirtą ir aštuntą tyrimo savaites, aštuntą savaitę skirti tetravalenčiai gripo skiepai. 12 savaitę hemaglutinacijos slopinimo (HAI) ir mikroneutralizacijos (MN) tyrimais buvo ịvertinti keturių gripo antigenų atmainų specifiniai antikūnų atsakai. 12 savaitę pacientų, vartojusių benralizumabą arba placebą, HAI arba MN antikūnų reakcijų skirtumų nenustatyta. Visų tirtų gripo padermių HAI geometrinis vidurkio padidejjimas (GMFR) buvo 3,3-4,2, vartojant benralizumabą, palyginus su 3,4-3,9 vartojant placebą; MN GMFR buvo 2,8-5,1 benralizumabo grupeje, palyginus su 3,2-4,4 placebo grupèje ( 9 pav.). HAI padidèjo $\geq 4$ kartus nuo aštuntos 
iki 12 savaitès atitinkamai $44,0-56,0$ proc. ir $30,6-49,0$ proc. pacientų, vartojusių benralizumabą ir placebą. 12 savaitę 78-100 proc., palyginus su 79,6-100 proc. pacientų, vartojusių atitinkamai benralizumabą ir placebą, pasiekè $\geq 40 \mathrm{HAI}$ antikūnų titrą. Nenustatyta ir reikšmingų saugumo profilị keičiančių reakcijų.

Benralizumabas neturejjo ittakos antikūnų atsakui i sezoninius viruso skiepus paaugliams ir jauno amžiaus suaugusiems pacientams, sergantiems vidutinio sunkumo arba sunkia astma. Ir tai irodyta klinikiniais tyrimais.

\section{BENRALIZUMABO \\ SAUGUMO PROFILIS}

Benralizumabo saugumas vartoti įrodytas keleto didelès imties tyrimų metu.

Atliktas atsitiktinių imčių dvigubai aklas, paralelinių grupių, trečios fazès tęstinis tyrimas BORA [44] 447 centruose 24 šalyse. I tyrimą ịtraukti pacientai, kurie baigé dalyvavimą SIROCCO [8] arba CALIMA [9] tyrimuose bei toliau gydèsi benralizumabo injekcijomis po oda - 30 mg kas keturias arba kas aštuonias savaites. Minètuose tyrimuose vartoję placebą pacientai atsitiktine tvarka specialios internetinès programos pagalba suskirstyti santykiu 1:1 i grupes: vieniems skirta vartoti benralizumabo $30 \mathrm{mg}$ kas keturias arba kas aštuonias savaites (kai pirmos trys vaisto dozès suleistos kas keturias savaites). Suaugę tiriamieji gydyti 56 savaites, paaugliai (12-17 metų amžiaus) 108 savaites. Pirminè vertinamoji baigtis buvo dviejų skirtingų benralizumabo dozavimo schemų saugumas ir toleravimas - vertinant iki 68 savaičių suaugusiems pacientams (iskaitant stebėsenos vizitus po gydymo) ir iki 56 savaičių paaugliams. Ši vertinamoji baigtis buvo įvertinta analizuojant visų pacientų, gydytų SIROCCO [8] ir CALIMA [9] tyrimuose ir gavusiu nors vieną vaisto dozę BORA [44] tyrime, bet neittrauktų i joki kitą tyrimą, duomenis.

Tyrime dalyvavo 1926 pacientai, iš kurių SIROCCO arba CALIMA tyrimuose 633 buvo gydyti benralizumabu kas keturias savaites, o 639 - kas aštuonias savaites. Likę 654 pacientai minètuose tyrimuose buvo vartoję placebą ir BORA tyrime atsitiktinai suskirstyti į benralizumabo, vartojamo kas keturias savaites $(n=320)$, arba benralizumabo, vartojamo kas aštuo-
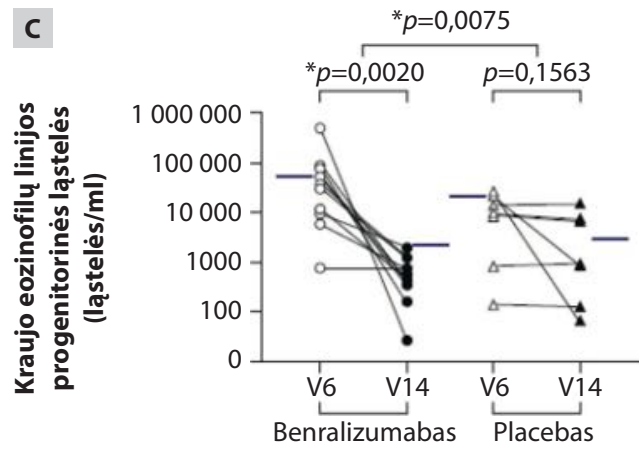

D

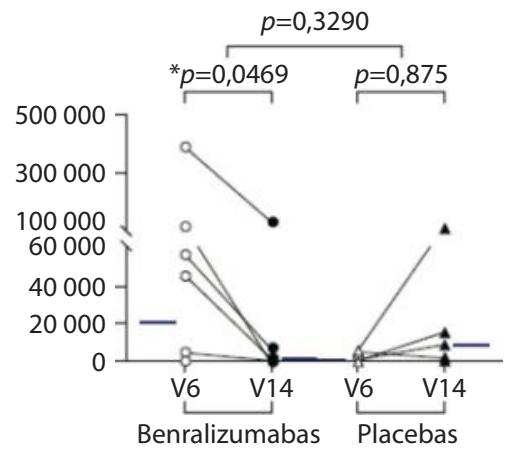

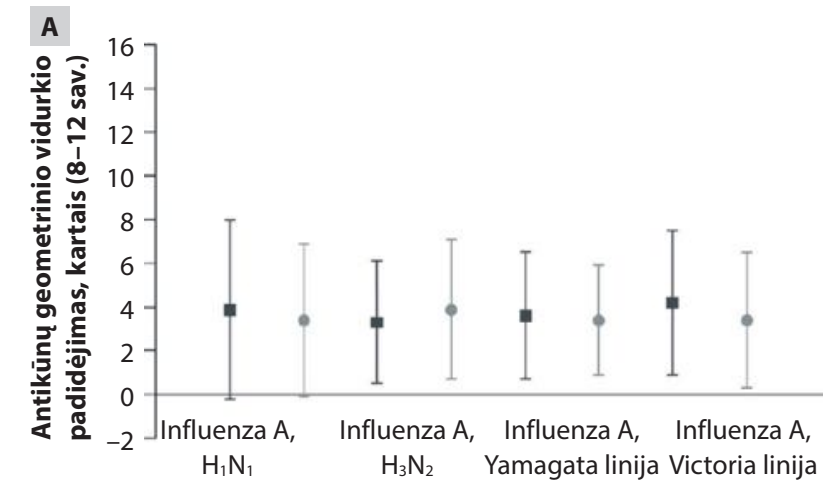

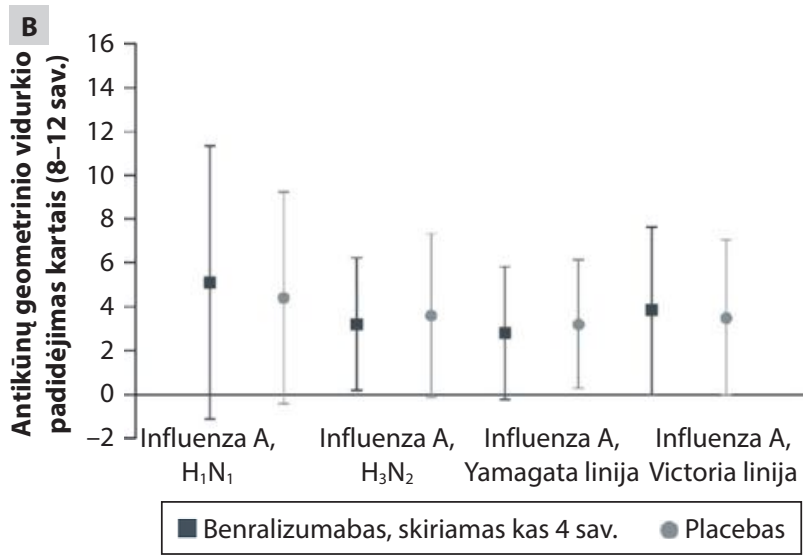

9 pav. Gripo atmainų antikūnų geometrinio vidurkio padidèjimas nuo aštuntos iki 12 savaitès (A) hemagliutinacijos slopinimui ir (B) mikroneutralizavimui (skiepų imunogeniškumo analizès rinkinys) [43] Duomenys pateikti parodant ir geometrinį standartinį nuokrypi 


\section{Farmakoterapija}

nias savaites $(\mathrm{n}=334)$, grupes. I analizę ịtraukti 1576 pacientai, iš jų 783 vartojo benralizumabą kas keturias savaites (265 naujai pradeti gydyti) ir 793 pacientai, kuriems buvo skirtas benralizumabas kas aštuonias savaites (281 naujai pradèti gydyti).

Visose grupèse dažniausi nepageidaujami poveikiai buvo virusinè viršutinių kvèpavimo takų infekcija (14-16 proc.) ir astmos simptomų suintensyvejimas (7-10 proc.). Dažniausiai pasitaikantys sunkūs nepageidaujami poveikiai buvo astmos paūmejjimas (3-4 proc.), pneumonija (iki 1 proc.) ir bakterinès infekcijos sukelta pneumonija ( $0-1$ proc.). Pacientu, kuriems gydymo metu pasireiškè koks nors nepageidaujamas poveikis, bet koks sunkus nepageidaujamas poveikis arba bet koks nepageidaujamas poveikis, lèmęs gydymo nutraukimą BORA tyrimo metu, dalis buvo panaši tarp gydytų placebu ir benralizumabu (ir tarp skirtingų benralizumabo gydymo schemų).

Nauji piktybinių navikų atvejai nustatyti 12 tiriamujuc (1 proc.) iš 1576 pacientų (po keturis kiekvienoje grupejje [1-2 proc.], išskyrus tyrimo grupę, kuriai naujai skirtas benralizumabas kas aštuonias savaites ir jokių naujų piktybinių navikų tyrimo metu nenustatyta.

Pacientų, kuriems pasireiškè koks nors nepageidaujamas poveikis, dalis buvo panaši tarp SIROCCO arba CALIMA (71-75 proc. - tik benralizumabo grupè) ir BORA (65-71 proc.), taip pat pacientų, kuriems pasireiškè nepageidaujami poveikiai, dèl kurių gydymas buvo nutrauktas (2 proc. SIROCCO ir CALIMA, palyginus su 2-3 proc. BORA tyrime).

Dviejų metų saugumo rezultatai parodè, kad, vartojant benralizumabą antrus metus, saugumo profilis išliko panašus. Naujų ilgalaikio eozinofilų sunaikinimo pasekmių neatsirado, o kitų nepageidaujamų poveikių, ìskaitant oportunistines infekcijas, dažnis antraisiais metais buvo panašus.

\section{EOZINOFILŲ SUNAIKINIMO [TAKA TUMOROGENEZEI}

Uždegimas gali būti naudingas atkuriant pažeistus audinius, tačiau lètinis uždegimas yra susijęs su daugelio vèžio rūšių išsivystymu ir progresavimu [45]. Epidemiologinių ir klinikinių tyrimų duomenimis, $\geq 20$ proc. visų vėžio atvejų prasideda kaip lètinès uždegiminès ligos pasekmė $[46,47]$. Irodyta, kad nereguliuojamas augimo veiksnių ir deguonies rūšių susidarymas sukelia genetinius pokyčius ir lemia auglio vystymosi pradžią. Uždegiminiai tarpininkai (mediatoriai) taip pat turi įtaką naviko augimui, piktybinei konversijai ir metastazių plitimui, tiesiogiai veikdami vèžio ląsteles ir naviko mikroaplinką $[45,48]$.

Nustatyta, kad eozinofilai infiltruoja ịvairius solidinius ir hematologinius navikus. Tačiau sudètinga ịvertinti prieštaringą eozinofilų priešvèžinị poveikị sergantiesiems vèžiu [48]. Pagrindinis kylantis klausimas, ar eozinofilų nebuvimas keičia naviko progresavimo greiti. Ar eozinofilų infiltracija yra susijusi su palankia arba nepalankia prognoze, išlieka ginčytina. Panašu, kad tai priklauso nuo daugelio veiksnių, daugiausia nuo vèžio rūšies [49]. Atliekant tyrimus su tiesiosios žarnos / gaubtinès ir tiesiosios žarnos vẻžiu [50, 51], burnos plokščiųjų ląstelių karcinoma [52], plaučių adenokarcinoma [54] ir nosiaryklès karcinoma [53], pastebėtas ryšys tarp eozinofilų infiltracijos ir ilgesnio išgyvenamumo. Panašūs rezultatai gauti ir sergantiesiems prostatos vèžiu [54]. Kai kuriems, bet ne visiems pacientams, sergantiems Hodžkino limfoma [55-57], išsètine mieloma [58] arba gimdos kaklelio vèžiu, eozinofilų infiltracija siejama su bloga prognoze. Ryšys tarp ilgalaikio išgyvenimo ir mažo eozinofilų kiekio, sergantiesiems plaučių vẻžiu, parodè, kad eozinofilai gali prisidèti prie plaučių tumorogenezès [59].

Atsižvelgiant ị lètinio uždegimo svarbą vystantis vèžiui, buvo ištirtas ryšys tarp uždegiminių ligų, tokių kaip astma, ir piktybinių navikų dažnio. Keletas tyrimų rado ryšį tarp astmos ir plaučių vẻžio rizikos. Suomių [60] ir švedų [61] pacientams, sergantiems astma, nustatyta padidejusi plaučių věžio rizika. Moterų (atitinkamai - 1,66 ir 1,78) standartinis dažnio santykis yra šiek tiek didesnis nei vyrų (atitinkamai 1,32 ir 1,51). 18 tyrimų, 1,6 milijono pacientų, sergančių astma, metaanalizè parodẻ reikšmingą ryši tarp astmos ir didesnès bendrosios plaučių vėžio rizikos [62]. Koreliacijų tarp astmos ir plaučių vẻžio vertinimą dažnai apsunkina tabako rūkymas. Vis dèlto plaučių vėžio rizika yra padidejjusi tiek rūkaliams (šansų santykis (ŠS) 1,35 ; 95 proc. pasikliautinasis intervalas [PI] 1,15-1,59) [63], tiek nerūkantiems, tačiau sergantiems astma asmenims (ŠS 1,28; 95 proc. PI 1,10-1,50) [62].

Keli ikiklinikiniai tyrimai išnagrinejo galimus mechanizmus, siejančius eozinofilus su vėžiu, ypatingą dèmesị skirdami IL-5 [5]. Nors pradiniai tyrimai parodè, kad IL-5 nepakeitė plaučių naviko susidarymo, vèlesniuose pranešimuose pažymèta, kad IL-5 sustiprino adenokarcinomos sukeltą piktybinị pleuritą ir palengvino metastazavimą distalinèje plaučių mikroaplinkoje. IL-5 gali gaminti ir plaučiuose esantys eozinofilai [64]. Skiriant eozinofilų kiekį mažinančius vaistus, neaišku, ar galima pelių tyrimų rezultatus pritaikyti žmonèms, juolab, kad benralizumabas nesijungia su pelių IL-5Ra [5]. Benralizumabas prisijungia prie žmogaus ir tam tikros rūšies beždžionių eozinofilų IL-5Ra, o tai rodo, kad tai yra tinkamesnis modelis benralizumabo tyrimams [5]. Pakartotinių dozavimo tyrimų, atliktų iki 39 savaičių, su tam tikros rūšies beždžionèmis, metu nenustatyta jokių neigiamų organų svorio pokyčių, jokių histologinių duomenų, rodančių preneoplastinius pažeidimus [5].

Nèra ịrodymų, kad gydymo, genetinių manipuliacijų arba patologinių procesų nulemtas nuolatinis mažas 
eozinofilų kiekis arba jų nebuvimas padidintų piktybinių navikų dažnị. Kontroliuojamųjų astmos tyrimų metu, skiriant mepolizumabą arba reslizumabą iki vienerių metų trukmès, naujai atsirandančių piktybinių navikų dažnis buvo $<1$ proc. ir buvo panašus i placebo $[65,66]$. Tęstinio tyrimo metu nustatytas piktybinių navikų dažnis, skiriant mepolizumabą, buvo šeši iš 347 atvejų (2 proc., kai stebėsena vykdyta iki 4,5 metų); 12 iš 1051 atvejų, skiriant reslizumabą (1,1 proc., kai stebėsena vykdyta iki dviejų metų gydymo trukmès [5]. Panašūs rezultatai užfiksuoti ir benralizumabą vienerius metus vartojantiems pacientams, atliekant ir 56 savaičiu stebėsenos tyrimą (atitinkamai - 4/1663 [0,24 proc.] ir 12/1576 [0,8 proc.]) [5]. Nuo kontroliuojamo gydymo laikotarpio pradžios iki pratęsimo laikotarpio pabaigos (iki dviejų metų) pacientų, nuolat vartojusių benralizumabą, piktybinių navikų dažnis buvo 8/1030 (0,8 proc.).

Navikų infiltracija eozinofilais yra dažna, deja, eozinofilų telkimosi priežastys ir pasekmès tumorogenezei nèra pakankamai ištirtos. Yra duomenų, kad su naviku susijusi eozinofilija gali būti epifenomenas, susijęs su eozinofilų išskiriamomis biologiškai aktyviomis medžiagomis arba naviko stadija [5]. Visų pirma, pacientams, kuriems stinga eozinofilų, dèl imunodeficito arba dèl imunoglobulino G sukelto eozinofilų pirmtakų sunaikinimo, nèra jokių skiriamųjų nuokrypių, susijusių su eozinofilų kiekio sumažejimu [5]. Prieš sukuriant biologinès terapijos vaistus, GGK, kurie taip pat naikina eozinofilus, buvo vartojami dešimtmečiais nesant duomenų apie didesnị piktybinių navikų dažnị [5].

Taigi, vertinant atliktus tyrimus, nepakanka duomenų teigti, kad gydymas slopinant IL-5 signalinị kelią (pvz., benralizumabu) didina tumorogenezès riziką.

\section{BENRALIZUMABO VARTOJIMO PATOGUMAS}

Nepaisant geresnio biologinès terapijos vaistų, skirtų astmai gydyti, prieinamumo, išlieka neaišku, kam pacientai ir gydytojai teikia pirmumą. Atliktas tyrimas [67], kurio tikslas buvo ịvertinti biologinès terapijos vartojimo trūkumus ir privalumus. Tyrimo metu vykdytos apklausos ir pokalbiai telefonu su pacientais ir gydytojais iš Jungtinių Amerikos Valstijų (JAV). Tyrimo dalyviai nurodé, kam skirtų pirmumą, o kur įžvelgia trūkumus, kliūtis. Tyrimo dalyviai ịvertino, suskirstè ir nurodè prioritetų svarbą pagal skirtingus požymius, ịskaitant: vartojimo būdą, skyrimo tvarką, dozavimo dažni, injekcijų skaičių, poveikio pasireiškimo laiką. Taip pat buvo įvertintos ir kitos savybès, būdingos kiekvienai grupei.

Atliktas tyrimas, kuriame dalyvavo 47 pacientai ir 25 gydytojai. Kaip svarbiausius požymius pacientai nurode gydymui tenkančias išlaidas, vaisto vartojimo būdą, laiką, kai pasireiškia vaisto veiksmingumas nuo jo vartojimo pradžios, skyrimo tvarką. Gydytojai svarbiausiais išskyrè vartojimo būdą, laiką iki gydomojo poveikio pasireiškimo nuo vaisto vartojimo pradžios, dozavimo dažni ir kompensavimo tvarką / vaisto prieinamumą (10 pav.). Abi grupès pirmumą teikè retesniam vaistų vartojimui / skyrimui (t. y. kas aštuonias savaites, palyginus su keturiomis arba dviem savaitėmis) ( $\mathrm{p}<0,01)$; taip pat poodinėms injekcijoms, palyginus su intraveninemis $(\mathrm{p}<0,0001)$. Pagrindinès pacientų ivvardytos problemos vartojant biologinius vaistus - vieta, kur juos susileisti, vartojimo režimas, kompensavimas / draudimo išmokos vaistui įsigyti, injekcijų skaičius ir vartojimo būdas. Gydytojai kaip pa-

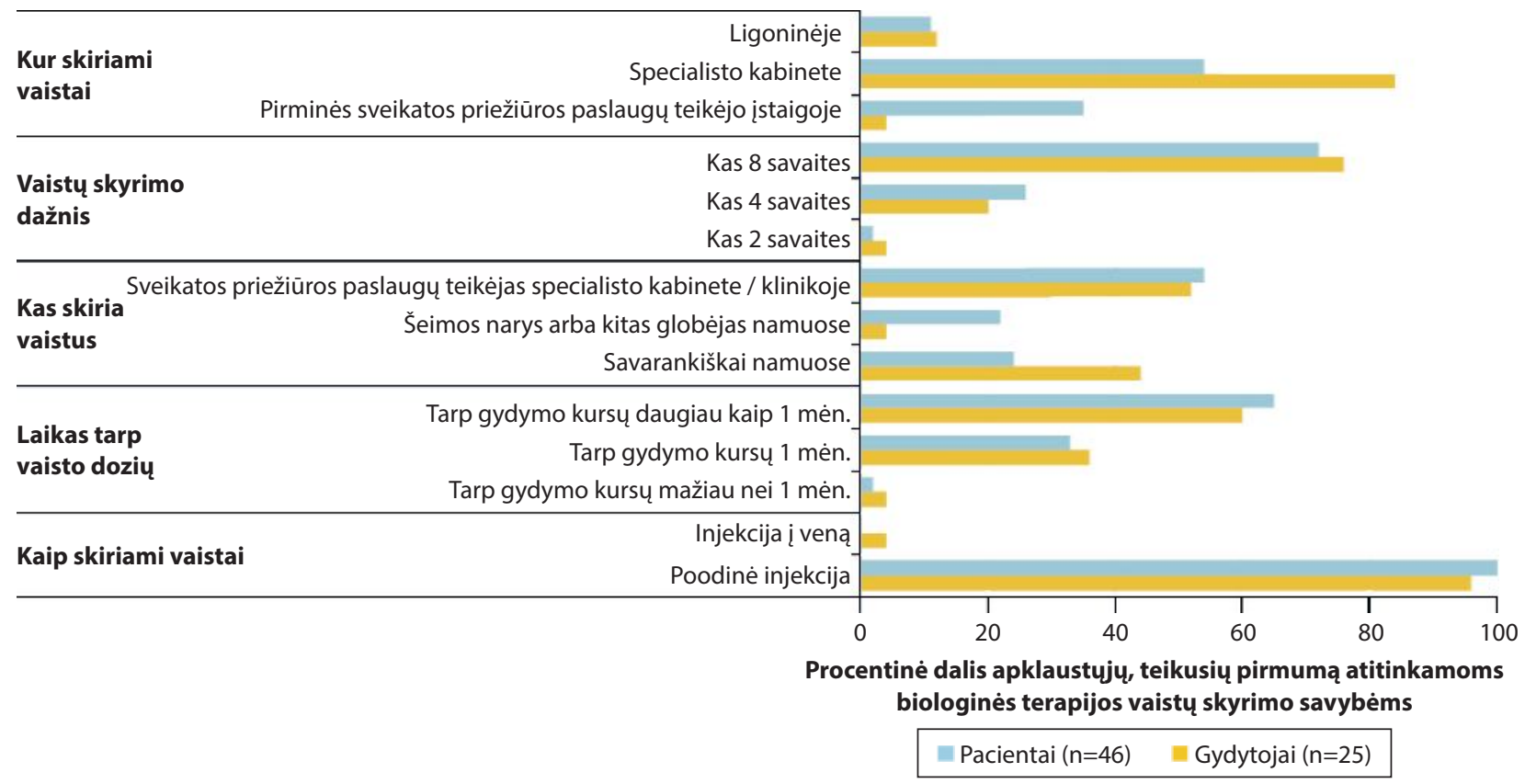

10 pav. Biologinių vaistų savybèms teikiamas pirmumas [67] 


\section{Farmakoterapija}

grindines kliūtis, pradedant gydymą, ịvardijo pacientų atitikimą gauti vaistą, pacientų ịtikinimą, administravimo tvarką, vartojimo būdą, kainą ir administracinę naštą; jau vartojant vaistus: veiksmingumas ir laikas, per kuri jis pasireiškia nuo vaisto vartojimo pradžios, vartojimo patogumas, kaina ir paciento atitiktis. Tiek pacientai, tiek gydytojai išreiškè pirmumą retesniam dozavimui, poodiniam vaisto skyrimo būdui, greitesnei vaisto veikimo pradžiai. Pagrindinès kliūtys: tenkančios išlaidos / draudimo išmokos ir patogumas (10 pav.). Geresnis privalumų ir kylančių kliūčių supratimas gali būti naudingas palengvinant gydytojo ir paciento pokalbius siekiant individualizuoti astmos gydymą.

Benralizumabas pasižymi patogiu vartojimo būdu (po oda, užpildyto švirkštiklio forma sudaro galimybes pacientams vaistą susileisti patiems jiems patogiu laiku), yra kompensuojamasis vaistas, o pacientams labai svarbu - nereikia dažnai lankytis pas gydytoją, t. y. po keturių kursų užtenka apsilankyti tik kartą per aštuonias savaites.

\section{APIBENDRINIMAS}

Biologinès terapijos benralizumabu veiksmingumas, gydant sunkią eozinofilinę astmą, ịrodytas didelès imties tyrimuose. Efektyviai slopinant lètinį eozinofilinị uždegimą (eozinofilai sunaikinami per 24 val.), pavyksta sumažinti arba išvengti astmos paūmèjimų, pagerejja plaučių funkcija (PEF pagereja jau antrą gydymo dieną, TVBA poreikis žymiai sumažejją trečią gydymo dieną, reikšmingas $\mathrm{FEV}_{1}$ pokytis nustatomas vos per savaitę, pagerèja astmos kontrolè, atsiranda galimybẻ sumažinti arba visiškai atsisakyti palaikomųjų GGK dozių, keičiasi gyvenimo kokybė. Žinant, kad eozinofilai yra imuninès ląstelès, atsiranda nerimas, bijant susilpninti apsaugines organizmo savybes, paskatinti tumorogenezę. Tyrimais nustatyta, kad benralizumabas neturi įtakos antikūnų atsakui paaugliams ir jauno amžiaus suaugusiems pacientams, sergantiems vidutinio sunkumo arba sunkia astma bei gydomiems benralizumabu. Kalbant apie tumorogenezę, nẻra patikimų įrodymų, kad gydymo nulemtas nuolatinis mažas eozinofilų kiekis arba jų nebuvimas padidintų piktybinių navikų dažnị. Prieš sukuriant biologinès terapijos vaistus, GGK, kurie taip pat naikina eozinofilus, buvo vartojami dešimtmečiais, nesant duomenų apie didesnị piktybinių navikų dažnį. LT-0791-08020-R\&I Straipsni remia $U A B$,AstraZeneca“

\section{LITERATŪRA}

1. Global Asthma Network. The global asthma report. 2020. https://ginasthma.org/wp-content/uploads/2020/06/GINA2020-report_20_06_04-1-wms.pdf. Accessed 31 Jul 2020.

2. Chung KF, Wenzel SE, Brozek JL, Bush A, Castro M, Sterk PJ, et al. International ERS/ATS guidelines on defnition, evaluation and treatment of severe asthma. Eur Respir J. 2014; 43(2):343-73.

3. Price D, Wilson AM, Chisholm A, Rigazio A, Burden A, Thomas M, et al. Predicting frequent asthma exacerbations using blood eosinophil count and other patient data routinely available in clinical practice. J Asthma Allergy. 2016; 9:1-12.

4. Talini D, Novelli F, Bacci E, Bartoli M, Cianchetti S, Costa F, et al. Sputum eosinophilia is a determinant of FEV1 decline in occupational asthma: results of an observational study. BMJ Open. 2015; 5(1):e005748.

5. Jackson DJ, Korn S, Mathur SK, Barker P, Meka VG, Martin UJ, et al. Safety of eosinophil-depleting therapy for severe, eosinophilic asthma: focus on benralizumab. Drug Saf. 2020; 43(5):409-25.

6. Takatsu K. Interleukin- 5 and IL-5 receptor in health and diseases. Proc Jpn Acad Ser B Phys Biol Sci. 2011; 87(8):463-85.

7. Kolbeck R, Kozhich A, Koike M, Peng L, Andersson CK, Damschroder MM, et al. MEDI-563, a humanized anti-IL-5 receptor alpha $\mathrm{mAb}$ with enhanced antibody-dependent cellmediated cytotoxicity function. J Allergy Clin Immunol. 2010; 125(6):1344-53.e2.

8. Bleecker ER, FitzGerald JM, Chanez P, Papi A, Weinstein SF, Barker P, et al. Efficacy and safety of benralizumab for patients with severe asthma uncontrolled with high-dosage inhaled corticosteroids and long-acting $\beta 2$-agonists (SIROCCO): a randomised, multicentre, placebo-controlled phase 3 trial. Lancet. 2016; 388(10056):2115-27.

9. FitzGerald JM, Bleecker ER, Nair P, Korn S, Ohta K, Lommatzsch $\mathbf{M}$, et al. Benralizumab, an anti-interleukin-5 receptor a monoclonal antibody, as add-on treatment for patients with severe, uncontrolled, eosinophilic asthma (CALIMA): a randomised, double-blind, placebo-controlled phase 3 trial. Lancet. 2016; 388(10056):2128-41.

10. Nair P, Wenzel S, Rabe KF, Bourdin A, Lugogo NL, Kuna P, et al. Oral glucocorticoid-sparing effect of benralizumab in severe asthma. N Engl J Med. 2017; 376(25):2448-58.

11. Abdala-Valencia $H$, Coden ME, Chiarella SE, Jacobsen EA, Bochner BS, Lee JJ, et al. Shaping eosinophil identity in the tissue contexts of development, homeostasis,and disease. J Leukoc Biol. 2018; 104(1):95-108.

12. Chusid MJ. Eosinophils: friends or foes? J Allergy Clin Immunol Pract. 2018; 6(5):1439-44.

13. Domachowske JB, Dyer KB, Bonville CA, Rosenberg HF. Recombinant human eosinophil-derived neurotoxin/RNase 2 functions as an effective antiviral agent against respiratory syncytial virus. J Infect Dis. 1998; 177(6):1458-64.

14. Drake MG, Bivins-Smith ER, Proskocil BJ, Nie Z, Scott GD, Lee JJ, et al. Human and mouse eosinophils have antiviral activity against parainfluenza virus. Am J Respir Cell Mol Biol. 2016; 55(3):387-94.

15. Samarasinghe AE, Melo R, Duan S, LeMessurier KS, Liedmann S, Surman SL, et al. Eosinophils promote antiviral immunity in mice infected with influenza A virus. J Immunol. 2017; 198(8):3214-26.

16. Phipps S, Lam CE, Mahalingam S, Newhouse M, Ramirez R, Rosenberg HF, et al. Eosinophils contribute to innate antiviral immunity and promote clearance of respiratory syncytial virus. Blood. 2007; 110(5):1578-86.

17. Ochkur SI, Jacobsen EA, Protheroe CA, Biechele TL, Pero RS, McGarry MP, et al. Coexpression of IL-5 and eotaxin-2 in mice created an eosinophil-dependent model of respiratory inflammation with characteristics of severe asthma. J Immunol. 2007; 178(12):7879-89.

18. Domachowske JB, Dyer KD, Adams AG, Leto TL, Rosenberg HF. Eosinophil cationic protein/RNase 3 is another RNase Afamily ribonuclease with direct antiviral activity. Nucleic Acids Res. 1998; 26(14):3358-63.

19. Harrison AM, Bonville CA, Rosenberg HF, Domachowske JB. Respiratory syncytical virus-induced chemokine expression in the lower airways: eosinophil recruitment and degranulation. Am J Respir Crit Care Med. 1999; 159(6):1918-24.

20. Percopo CM, Dyer KD, Ochkur SI, Luo JL, Fischer ER, Lee JJ, et al. Activated mouse eosinophils protect against lethal respiratory virus infection. Blood. 2014; 123(5):743-52.

21. Ravin KA, Loy M. The eosinophil in infection. Clin Rev Allergy Immunol. 2016; 50(2):214-27.

22. Svensson L, Wenneras C. Human eosinophils selectively recognize and become activated by bacteria belonging to diferent taxonomic groups. Microbes Infect. 2005; 7(4):720-8.

23. Davido B, Makhlouf S, Matt M, Calin R, Senard O, Perronne C, et al. Changes in eosinophil count during bacterial infection: 
revisiting an old marker to assess the efcacy of antimicrobial therapy. Int J Infect Dis. 2017; 61:62-6.

24. Shaaban H, Daniel S, Sison R, Slim J, Perez G. Eosinopenia: is it a good marker of sepsis in comparison to procalcitonin and C-reactive protein levels for patients admitted to a critical care unit in an urban hospital? J Crit Care. 2010; 25(4):570-5.

25. Huang L, Appleton JA. Eosinophils in helminth infection: defenders and dupes. Trends Parasitol. 2016; 32(10):798-807.

26. Fabre V, Beiting DP, Bliss SK, Gebreselassie NG, Gagliardo LF, Lee NA, et al. Eosinophil defciency compromises parasite survival in chronic nematode infection. J Immunol. 2009, 182(3):1577-83.

27. Babayan SA, Read AF, Lawrence RA, Bain O, Allen JE. Filarial parasites develop faster and reproduce earlier in response to host immune efectors that determine flarial life expectancy. PLoS Biol. 2010; 8(10):e1000525.

28. Jesenak M, Schwarze J. Lung eosinophils-A novel "virus sink" that is defective in asthma? Allergy. 2019; 74(10):1832-4.

29. Ravanetti L, Dijkhuis A, Sabogal Pineros YS, Bal SM, Dierdorp BS, Dekker T, et al. An early innate response underlies severe influenza-induced exacerbations of asthma in a novel steroid-insensitive and anti-IL-5-responsive mouse model. Allergy. 2016; 72(5):737-53.

30. Sabogal Piñeros YS, Bal SM, Dijkhuis A, Dijkhuis A, Majoor CJ, Dierdorp BS, et al. Eosinophils capture viruses, a capacity that is defective in asthma. Allergy. 2019; 74(10):1898-909.

31. Sehmi R, Lim HF, Mukherjee M, Huang C, Radford K, Newbold $\mathbf{P}$, et al. Benralizumab attenuates airway eosinophilia in prednisone-dependent asthma. J Allergy Clin Immunol. 2018; 141(4):1529-32.e8.

32. Mesnil C, Raulier S, Paulissen G, Xiao X, Birrell MA, Pirottin $\mathrm{D}$, et al. Lung-resident eosinophils represent a distinct regulatory eosinophil subset. J Clin Investig. 2016; 126(9):3279-95.

33. Qiu Y, Nguyen KD, Odegaard JI, Cui X, Tian X, Locksley RM, et al. Eosinophils and type 2 cytokine signaling in macrophages orchestrate development of functional beige fat. Cell. 2014; 157(6):1292-308

34. Jung Y, Wen T, Mingler MK, Caldwell JM, Wang YH, Chaplin DD, et al. IL-1beta in eosinophil-mediated small intestina homeostasis and IgA production. Mucosal Immunol. 2015; 8(4):930-42.

35. Marichal T, Mesnil C, Bureau F. Homeostatic eosinophils: character- istics and functions. Front Med. 2017; 4:101.

36. Sehmi R, Smith SG, Kjarsgaard M, Radford K, Boulet LP, Lemiere C, et al. Role of local eosinophilopoietic processes in the development of airway eosinophilia in prednisone-dependent severe asthma. Clin Exp Allergy. 2016; 46(6):793-802.

37. Smith SG, Chen R, Kjarsgaard M, Huang C, Oliveria JP, O'Bryne PM, et al. Increased numbers of activated group 2 innate lymphoid cells in the airways of patients with severe asthma and persistent airway eosinophilia. J Allergy Clin Immunol. 2016; 137(1):75-86.e8

38. Pham TH, Damera G, Newbold P, Ranade K. Reductions in eosinophil biomarkers by benralizumab in patients with asthma. Respir Med. 2016; 111:21-9.

39. Juhn YJ. Risks for infection in patients with asthma (or other atopic conditions): is asthma more than a chronic airway disease? J Allergy Clin Immunol. 2014; 134(2):247-57.

40. Yang $M$, Zhang $Y$, Chen $H$, Lin J, Zeng J, Xu Z. Inhaled corticosteroids and risk of upper respiratory tract infection in patients with asthma: a meta-analysis. Infection. 2019; 47(3):377-85.

41. Pesek R, Lockey R. Vaccination of adults with asthma and COPD. Allergy. 2011; 66(1):25-31.

42. Vasileiou E, Sheikh A, Butler C, El Ferkh K, von Wissmann B, McMenamin J, et al. Effectiveness of influenza vaccines in asthma: a systematic review and meta-analysis. Clin Infect Dis. 2017; 65(8):1388-95

43. Zeitlin PL, Leong M, Cole J, Mallory RM, Shih VH, Olsson RF, et al. Benralizumab does not impair antibody response to seasonal influenza vaccination in adolescent and young adult patients with moderate to severe asthma: results from the Phase IIIb ALIZE trial. J Asthma Allergy. 2018; 11:181-92.

44. Busse WW, Bleecker ER, FitzGerald JM, Ferguson GT, Barker P, Sproule S, et al. Long-term safety and efficacy of benralizumab in patients with severe, uncontrolled asthma: 1-year results from the BORA phase 3 extension trial. Lancet Respir Med. 2019; 7(1):46-59

45. Liu J, Lin PC, Zhou BP. Inflammation fuels tumor progress and metastasis. Curr Pharm Des. 2015; 21(21):3032-40.

46. Coussens LM, Werb Z. Inflammation and cancer. Nature. 2002; 420(6917):860-7.

47. Todoric J, Antonucci L, Karin M. Targeting inflammation in cancer prevention and therapy. Cancer Prev Res (Phila). 2016; 9(12):895-905.

48. Reichman H, Karo-Atar D, Munitz A. Emerging roles for eosinophils in the tumor microenvironment. Trends Cancer. 2016; 2(11):664-75.

49. Sakkal S, Miller S, Apostolopoulos V, Nurgali K. Eosinophils in cancer: favourable or unfavourable? Curr Med Chem. 2016; 23(7):650-66.

50. Fisher ER, Paik SM, Rockette H, Jones J, Caplan R, Fisher B. Prognostic significance of eosinophils and mast cells in rectal cancer: findings from the National surgical adjuvant breast and bowel project (protocol R-01). Hum Pathol. 1989; 20(2):159-63.

51. Nielsen HJ, Hansen U, Christensen IJ, Reimert CM, Brunner $\mathbf{N}$, Moesgaard F. Independent prognostic value of eosinophi and mast cell infiltration in colorectal cancer tissue. J Pathol. 1999; 189(4):487-95.

52. Jain M, Kasetty S, Sudheendra US, Tijare M, Khan S, Desai A. Assessment of tissue eosinophilia as a prognosticator in oral epithelial dysplasia and oral squamous cell carcinoma-an image analysis study. Patholog Res Int. 2014; 2014:507512.

53. Fujii M, Yamashita T, Ishiguro R, Tashiro M, Kameyama K. Significance of epidermal growth factor receptor and tumor associated tissue eosinophilia in the prognosis of patients with nasopharyngeal carcinoma. Auris Nasus Larynx. 2002; 29(2):175-81.

54. McNeel DG, Gardner TA, Higano CS, Kantoff PW, Small EJ, Wener MH, et al. A transient increase in eosinophils is associated with prolonged survival in men with metastatic castration-resistant prostate cancer who receive sipuleucel-T. Cancer Immunol Res. 2014; 2(10):988-99.

55. Molin D. Bystander cells and prognosis in Hodgkin lymphoma. Review based on a doctoral thesis. Ups J Med Sci. 2004; 109(3):179-228.

56. Samoszuk M. Eosinophils and human cancer. Histol Histopathol. 1997; 12(3):807-12.

57. Keresztes K, Szollosi Z, Simon Z, Tarkanyi I, Nemes Z, Illes A. Retrospective analysis of the prognostic role of tissue eosinophil and mast cells in Hodgkin's lymphoma. Pathol Oncol Res. 2007; 13(3):237-42

58. Wong TW, Kita H, Hanson CA, Walters DK, Arendt BK, Jelinek DF. Induction of malignant plasma cell proliferation by eosinophils. PLoS One. 2013; 8(7):e70554.

59. Varricchi G, Galdiero MR, Loffredo S, Lucarini V, Marone G, Mattei F, et al. Eosinophils: the unsung heroes in cancer? Oncoimmunology. 2018; 7(2):e1393134.

60. Vesterinen E, Pukkala E, Timonen T, Aromaa A. Cance incidence among 78,000 asthmatic patients. Int J Epidemiol. 1993; 22(6):976-82.

61. Boffetta P, Ye W, Boman G, Nyrén O. Lung cancer risk in a population-based cohort of patients hospitalized for asthma in Sweden. Eur Respir J. 2002; 19(1):127-33.

62. Qu YL, Liu J, Zhang LX, Wu CM, Chu AJ, Wen BL, et al. Asthma and the risk of lung cancer: a meta-analysis. Oncotarget. 2017; 8(7):11614-20.

63. Gonzalez-Perez A, Fernandez-Vidaurre C, Rueda A, Rivero E, Garcia Rodriguez LA. Cancer incidence in a general population of asthma patients. Pharmacoepidemiol Drug Saf. 2006; 15(2):131-8.

64. Ikutani $M$, Yanagibashi T, Ogasawara M, Tsuneyama K, Yamamoto S, Hattori Y, et al. Identifcation of innate IL-5-producing cells and their role in lung eosinophil regulation and antitumor immunity. J Immunol. 2012; 188(2):703-13.

65. Food Drug Administration Center for Drugs Evaluation Research. Mepolizumab (Nucala) medical review. Biologics license application (BLA). Review completion date: June 30, 2015. Available from: http://www.accessdata.fda.gov/drugsatfda docs/ nda/2015/125526Orig1s000MedR.pdf. Accessed 9 Jan 2020

66. Food Drug Administration Center for Drugs Evaluation Research. Reslizumab (Cinqair) medical review. Biologics license 67. application (BLA). Review date: March 14, 2016.

68. Gelhorn HL, Balantac Z, Ambrose CS, Chung YN, Stone B. Patient and physician preferences for attributes of biologic medications for severe asthma. Patient Prefer Adherence. 2019; $13: 1253-68$ 